\title{
Edinburgh and the Rise of Oceanography. ${ }^{1}$
}

\author{
By Prof. W. A. Herdman, C.B.E., F.R.S.
}

E DINBURGH may be regarded as the birthplace and the early home of modern oceanography, and Edinburgh men and Edinburgh ideas played a leading part during the nineteenth century in establishing this comprehensive science of the sea. Oceanography, if of modern development, is of ancient origin. The foundations upon which it has been recently built can be traced back to very early times, to the records of naturalists and the observations of seamen from the voyages of the Phœnicians onwards, and maps have been constructed to show the growth of our knowledge of the oceans from the shores of the Mediterranean in the time, say, of Homer, and later of Aristotle, on to the Atlantic voyages of the fifteenth and sixteenth centuries, and the circumnavigation of Magellan in $\mathrm{I}_{\mathbf{2}} \mathbf{2 2}$, when the first attempt, so far as we know, was made to sound the Pacific with a 200-fathom line at a spot we now know to be about 2000 fathoms deep. Pytheas, who first passed the Pillars of Hercules into the unknown Atlantic, and penetrated to British seas and brought back reports of Ultima Thule and of a sea to the north thick and sluggish, like a jelly-fish, was an early oceanographer in the fourth century B.c. ; and so, coming to later times, was that truly scientific navigator, Capt. James Cook, who sailed to the South Pacific on a transit of Venus expedition in 1769 , with Sir Joseph Banks as naturalist on board, and later circumnavigated the Southern Ocean about lat. $60^{\circ} \mathrm{S}$., and so finally disproved the existence of a great southern continent.

It is impossible in one short lecture to trace all stages and mention all worthy names, but a list of the more notable voyages of exploration in the nineteenth century recalls the names of the great men such as Darwin, Hooker, and Huxley, who went with the ships as naturalists, and all of whom contributed in their turn to our knowledge of the sea and its contents.

Information as to the bottom of the sea and the animals living there is obtained chiefly by dredging and trawling, and we find that the naturalist's dredge, a modification of the fisherman's oyster dredge, came into common use about I830, and was the chief implement employed by the marine biologists of the nineteenth century, who made known the riches of the British seas.

In tracing the development of the science of the sea, we may take as examples the work of three Edinburgh men, who are types of periods of investigation in the nineteenth centuryEdward Forbes, the pioneer of shallow-water dredging during the eariier half of the century; Wyville Thomson, the explorer of the deep sea and scientific leader of the Challenger expedition; and John Murray, who continued the work of Wyville Thomson and guided research in the last

1 Abridged from an evening discourse to the British Association at Edinburgh on September ${ }_{3}$.

NO. 27 I4, VOL. IO8] quarter-century into deeper and more fundamental problems of the ocean, and brought the science practically to its present position and outlook.

Edward Forbes, though of Scottish descent, was born in the Isle of Man about 100 years ago, but much of his short life and his remarkable work was connected with Edinburgh. His long and erratic career as a student of medicine and science was spent here, and he died a professor in the university of the city. As a mere boy in the Isle of Man he commenced his marine biological studies and the accumulation of those collections and observations which af terwards formed the basis of his classic works on "British Starfishes" and "British Mollusca." He left home at the age of seventeen, and from that time onwards the whole of his short, strenuous life was devoted to science and mainly to the science of the sea. $\mathrm{He}$ was a many-sided genius, who produced an extraordinary volume of first-rate original work in marine biology and inspired advances in oceanography which he did not live to see carried out.

After a short period of art study in London Forbes arrived in Edinburgh in 1831 as a medical student, and here he remained a student for nine years. It is interesting to note that our three selected leaders in science were all students of medicine in this university, and not one of them graduated. Forbes was the centre of a brilliant group of young medicals, about half a dozen of whom were afterwards fellow professors with him in the same university. The chief of these was perhaps John Goodsir, the famous anatomist, and in 1839 we find Forbes and Goodsir dredging in the Shetland seas, with results which Forbes made known to the meeting of the British Association at Birmingham that summer with such good effect that the celebrated "Dredging Committee" of the association was formed to continue the good work. Forbes and his British Association Dredging Committee may be said truly to have led on, step by step, to the Challenger and other expeditions of modern oceanography.

One very curious animal which Forbes and Goodsir made known from Hebridean seas is the bright-green compound Ascidian called Syntethys hebridica, which has since been shown to be the same as a Mediterranean animal of a lovely violet colour named by the French naturalist, Savigny, Diazona violacea. The animal in our seas is green when alive, but when it dies undergoes a chemical change and becomes violet. As an example of the constancy of Nature, I may add that nearly seventy years after this rare animal had been found by Forbes and Goodsir I went to the Hebridean seas to search for it, and in exactly the same spot, to the north of the Croulin Islands, came upon it in quantity sufficient to supply various museums and give material to my chemical friends who were investigating the pigment. 
Forbes's great opportunity to make marine investigations outside the British seas came in 184I, when he was appointed naturalist on the surveying ship Beacon engaged on hydrographic work in the eastern Mediterranean. His dredgings in the Agean gave great results and led to the well-known and much-discussed views on zones of life in the sea which are always associated with his name. He defined in the Ægean eight zones of depth, characterised by peculiar assemblages of animals, and he conjectured that the zero of animal life would probably be found somewhere about 300 fathoms-the "azoic" zone-a conclusion which has since been found to be erroneous. His Agean report was laid before the British Association in 1843 , and, we are told, at once raised the author to a high rank amongst living naturalists.

But perhaps Forbes's most important work of an oceanographic nature is the Geological Survey Memoir, in which he traces the origins of the British fauna and flora and their relations to geological changes in the past. $\mathrm{He}$ accounted, for example, for the five sub-floras which he defined as due to successive migrations from neighbouring lands previous to the isolation of the British Islands from the mainland of Europe. He showed the northern and southern relations of the fauna of our seas, as exemplified by the fishes and the molluscs, and the presence of "Boreal outliers," assemblages of northern species occupying deeper areas of 80 to 100 fathoms on the west of Scotland. These he regarded as portions of the original northern fauna which formerly occupied our seas and had retreated northwards when the climate became more genial subsequent to the Glacial epoch, leaving these colonies isolated in the deeper holes. Forbes's theories on distribution and on the origin of the British fauna and flora, even if in part erroneous, were a notable contribution to knowledge, and far in advance of anything known at the time, and had an important influence on the history of further investigation. His theories, along with his descriptive work, form a wonderful output both in quantity and quality for a man to have produced who died before reaching the age of forty, only six months after he had attained to the goal of his ambition, the chair of natural history in the University of Edinburgh.

Forbes was the most original, brilliant, and inspiring naturalist of his day, with a broad, philosophic outlook over Nature, and a capacity for investigating border-line problems involving several branches of science-he was, in a word, a pioneer of oceanography and the spiritual ancestor of men like Sir Wyville Thomson and Sir John Murray.

We now pass from this period of the early marine naturalists to that of the later oceanographers of the nineteenth century. If Forbes was the pioneer of shallow-water dredging, Wyville Thomson played a similar part in regard to the exploration of the depths of the ocean. No. 27 I4, VOL. IO8]
His name will go down through the ages as the leader of the famous Challenger expedition, by far the most important scientific deep-sea exploring expedition of all times. Wyville Thomson's work was in direct continuity with that of Forbes. It was Forbes who, on a basis of observations then thought to be sufficient, but now known to have been exceptional, placed the zero of life in the sea at 300 fathoms, and it was Wyville Thomson more than any man who proved that Forbes's views were in this respect erroneous, and that many and varied living things inhabit the greatest depths of the ocean.

Charles Wyville Thomson was born in 1830 at Bonsyde, near Linlithgow, and was in every sense, by ancestry and by education, a son of Edinburgh. Like Edward Forbes, he started as a medical student, but, fortunately for oceanography, after about three years of study, his health gave way, and he left medicine for what was then supposed to be the less strenuous pursuit of science. It is interesting to trace how Thomson's earliest investigations on fossils led on by successive steps to the novel and fruitful field of deep-sea exploration. Palæontological observations on Crinoids suggested work on the living Antedon, and that led to the investigation of the stalked larval stages of that Rosy Feather Star. Then the news that a strange new stalked Crinoid (Rhizocrinus lofotensis), related to the fossil Apiocrinidæ, and resembling the larval forms of Antedon, had been found living in northern seas induced him in 1866 to visit Prof. M. Sars at Christiania and examine for himself the remarkable collection of rare animals that the son, G. O. Sars, had brought up from more than 300 fathoms in the Lofoten fiords. Thomson was naturally much struck by their novelty and interest and their resemblance to extinct animals of former geological periods. Thus inspired, he urged his friend, Dr. W. B. Carpenter, with whom he was then working, to join him in endeavouring to promote an expedition to explore the deeper water of the Atlantic. Carpenter's powerful advocacy induced the council of the Royal Society to use their influence with the Hydrographer with such success that the Admiralty placed first one and then another small surveying steamer at the disposal of a scientific committee. Thus came about the cruises of the Lightning in I868 (when they dredged down to $65^{\circ}$ fathoms) and the Porcupine in 1869 and 1870 (when they reached the great depth of 2435 fathoms) which are described in detail in Wyville Thomson's book, "The Depths of the' Sea," the first general text-book of oceanography, published just after the Challenger had sailed in 1872 . These explorations showed an abundance of life at all depths.

Incidentally we may note that another Edinburgh professor-Fleeming Jenkin, the engineerwhen repairing a cable in the Mediterranean in I 860 brought up some sessile animals attached to the broken cable from more than 1000 fathoms. 
Wyville Thomson succeeded Allman as professor of natural history in Edinburgh in 1870 , and from that time Edinburgh became the active centre of deep-sea exploration. The undoubted success of the preliminary expeditions in the Lightning and Porcupine encouraged Carpenter and Thomson, again through the council of the Royal Society, in co-operation with a committee of the Council of the British Association, to induce the Government to equip a deep-sea expedition on a really grand scale to explore the conditions of life in the great oceans. This resulted in the famous circumnavigating expedition of the Challenger, with Sir Wyville Thomson as director of the scientific staff. On that staff were also two other Edinburgh men, J. Y. Buchanan; the chemist, and John Murray.

The Challenger sailed in December, 1872 , and returned in May, 1876 , and during that three and a half years traversed 70,000 miles of sea, dredging or trawling at 362 stations, and bringing back enormous collections, such as the scientific world had never seen. It is impossible in a few minutes to give any adequate idea of the discoveries of the Challenger expedition. Never did an expedition, which cost so little, produce such momentous results for human knowledge, and Edinburgh may fairly claim a share of the glory reflected from the expedition led by her famous Regius professor of natural history.

All naturalists. know how great were the additions to the scientific knowledge of the oceans and their inhabitants made either during the voyage or later in the working out of the collections, which was carried on during the following twenty years, to a very large extent in Edinburgh, partly in the Challenger office in Queen Street, and partly in some of the laboratories of the university.

Sir Wyville Thomson did not live to see the results of his great expedition worked out and published. Soon after the return home his health broke, and he died in 1882 . During the last years of his life Thomson arranged for two supplementary expeditions under Murray and Tizard to explore the Faroe Channel between the north of Scotland and the Faroe Isles. All three of our pioneers are connected with this region. Forbes long ago, in $185^{\circ}$, pointed out that it ought to be explored, as on the boundary of two faunas, the Arctic and the Atlantic, Thomson, in the Porcupine, discovered "cold" and "warm" areas at the bottom only an hour's sail apart and differing by $15^{\circ} \mathrm{F}$. ; and from Challenger temperature observations in the Pacific, etc., he predicted that a barrier would be found rising to 200 or 300 fathoms. Hence the Knight-Errant and Triton expeditions, in which Murray and Tizard discovered the "Wyville-Thomson" ridge separating cold Arctic water from warmer Atlantic.

For a quarter of a century after the Challenger expedition Edinburgh was the chief centre of oceanographic research, and the Mecca towards which marine biologists from all over the world turned to inspect the novelties of the wonderful collections and to discuss results, and in all this work many well-known Edinburgh men of scienceTurner, ' 'ait, Crum Brown, Geikie, Chrystal, Buchan, and others-played a leading part-outside the biological group of workers at the Challenger office.

After Sir Wyville Thomson's death it was fortunate for science and for the continuance of the influence of Edinburgh upon oceanographic research that Dr. John Murray, who had been chief assistant at the Challenger office since the return of the expedition, was able and willing to take up the directorship and bring the whole work to a most successful issue twenty years later. These two Scots share the honour of having guided the destinies of what is still the greatest oceanic exploration.

John Murray, though born in Canada, was of Scottish descent, and came as a boy to Scotland to complete his education. $\mathrm{He}$ also started as a student of medicine at the University of Edinburgh, and, again like his two forerunners, gave up medicine for science, and left without graduating. His first oceanographic expedition was to Spitsbergen and other parts of the Arctic regions on board a Peterhead whaler, on which, on the strength of having been once a medical student, he was shipped as surgeon. It was only an odd chance that led to Murray's connection with the Challenger. The scientific staff had already been definitely appointed when at the last moment one of the assistant naturalists dropped out, and on the recommendation of Prof. Tait, Murray was offered the vacant post.

On the expedition Murray devoted special attention to coral reefs, bottom deposits, and plankton, all of which have led to important results.

Murray's investigation of deposits led, moreover, to one of the romances of science when he discovered and exploited a very valuable phosphatic deposit on Christmas Island in the Indian Ocean. He was able to show, after some years' working of the deposit, that the British Treasury had received in taxes and royalties considerably. more than the total cost of the Challenger expedition. Even in his busiest years at the Challenger office Murray never gave up work at sea. In his little yacht, Medusa ( 38 tons), between 1884 and 1892 he explored the sea-lochs of the west of Scotland, made great collections and many observations, and found "Boreal outliers" in Loch Etive and Upper Loch Fyne.

It is curious that Edinburgh, so favourably situated on the Firth of Forth, and provided with such a succession of eminent professors as her university has had since the days of Jameson, has never had a permanent marine biological station. Murray at least made an attempt. In 1884 he acquired Granton quarry and moored in it the $A r k$ with biological and chemical laboratories. Murray and Irvine carried on chemical work while the $A r k$ was at Granton on the secretion of carbonate of lime, on the solu-

NO. 27 I4, VOL. IO8] 
tion of carbonate of lime in sea-water, and on chemical changes in muds, etc.

Murray's last oceanographic expedition was a four-months' cruise in Igro in the North Atlantic with Dr. Hjort in the Michael Sars when in his seventieth year. He was killed in a motor accident in March, Igr4.

There is, no doubt, other Edinburgh work in connection with oceanography, such as that of the Fishery Board for Scotland, which should be mentioned, and other names of those who are still happily with us and at work, such as the indefatigable arctic and antarctic explorer, Dr. W. S.
Bruce, the leader of the Scotia expedition, and the founder of the Edinburgh Oceanographic Laboratory; but in this brief record of the past it has been possible only to deal simply with the historically connected work of the three great pioneers of the nineteenth century-Edward Forbes, the dredger of the shallow waters; Wyville Thomson, the explorer of the deep seas; and John Murray, who may be regarded as the founder of modern post-Challenger oceanography -in demonstrating the effect of Edinburgh men and ideas and work in advancing our knowledge of the science of the sea.

\section{Absorption Spectra.}

\section{By Prof. E. C. C. Baly, C.B.E., F.R.S.}

W ITHOUT doubt the study of absorption spectra, more particularly those of organic compounds, has given rise to great interest, owing to the possible connection between absorption and chemical constitution. The work of Hartley, Dobbie, and others showed that in certain cases it was possible to determine the constitution of substances from observations of their absorption spectra. It is not surprising that, as the result of this work, a school of thought was founded on the basis of a direct correlation between the atomic structure of a molecule and its absorption spectrum. On the other hand, Hantzsch, who in a great number of papers has maintained the opinion that the absorption curve is an index to constitution, has travelled far beyond the original point of view. He found that changes in the absorption spectrum of a compound are observed when no change is possible in its primary valency structure, and in interpreting his results Hantzsch has invoked the aid of the secondary valencies of the atoms.

It is now known beyond any question of doubt that one and the same substance under different conditions can show different absorption spectra in the visible and ultra-violet. It is also known that, whilst a change in the primary structure of the molecule might possibly be accepted as an explanation of this in a few instances, the large majority of these variations in absorption cannot in any way be thus accounted for. Attempts were also made to interpret absorption spectra by oscillating linkages, such, for instance, as the equilibrium between the enolic and ketonic forms of ethyl acetoacetate or the oscillation that may be accepted as taking place within the benzene ring. This suggestion was very soon negatived when it was found that many substances in which no such oscillation is taking place exhibit well-marked absorption bands. For example, it might be possible to explain the ultra-violet absorption band of acetone by attributing it to the equilibrium $\mathrm{CH}_{3}-\mathrm{CO}-\mathrm{CH}_{3}=\mathrm{CH}_{3}-\mathrm{C}(\mathrm{OH})=\mathrm{CH}_{2}$; but hexamethylacetone, in which no such change is possible, exhibits the same absorption band as acetone.

$$
\text { NO. } 27 \text { I4, VOL. IO8] }
$$

The only other possible variable from the point of view of the chemist is the secondary valency, and this has been advanced by Hantzsch and others as the explanation of absorption in the visible and ultra-violet, the well-established differences in absorption being accounted for by different distributions of the secondary valencies. No physical explanation, however, has been offered of the assumed correlation between the secondary valency and absorptive power, a matter of great importance, since a theory cannot hold good unless some physical basis can be found for the phenomenon of the absorption of radiant energy.

In all this work the study of absorption spectra of organic compounds has been restricted to the visible and ultra-violet regions of the spectrum, and, indeed, only to that portion of the ultraviolet which is transmitted by a quartz spectrograph working in air. This is unfortunate, since the absorption bands exhibited by the compounds in that vast region known as the infra-red and in the extreme ultra-violet are ignored. Then, again, many inorganic substances show absorption bands which are exactly similar to those on which Hantzsch founds his valency formulæ of organic compounds, and obviously an identical explanation must be found for each class of compound. It is not too much to say that all the above theories have been based on insufficient data.

If the complete system of absorption bands shown by a compound over the whole spectrum is examined, it is found that the central frequency-namely, the frequency for which the absorptive power is the greatest-in any visible or ultra-violet band is always an exact multiple of the frequency of an important absorption band in the short-wave infra-red. Then, again, this infra-red frequency is itself an exact multiple of the central frequencies of well-marked bands in the long-wave infra-red. This integral relationship is of great importance, since it can readily be proved that the central frequencies are truly characteristic of the molecules, the subsidiary frequencies associated with them being probably due to the atoms and groups of atoms composing the molecules. Again, the changes in absorption ex- 